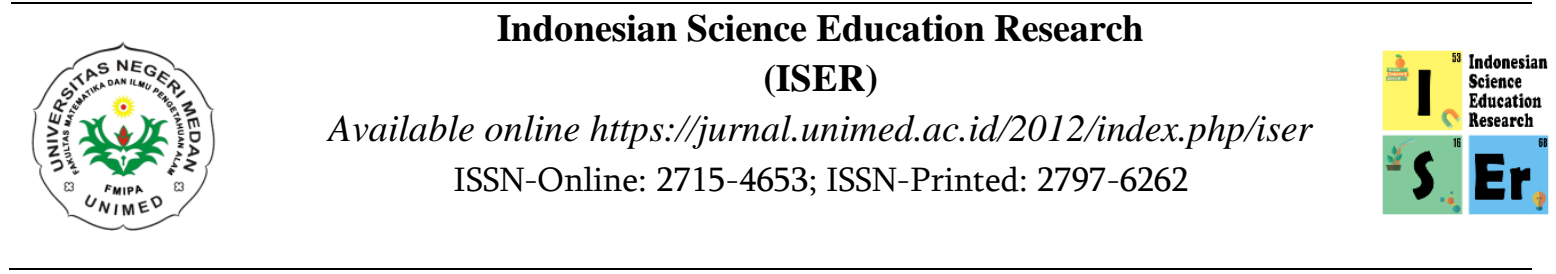

\title{
LEARNING MEDIA USED WHEN LEARNING DISTANCE: ANALYSIS OF STRENGTHS AND WEAKNESSES OF GOOGLE CLASSROOM IN DISTANCE LEARNING
}

\author{
Khovivah, A., Theresia, M., Utami, N., and Ardelia, T. \\ Department of Science Education, Faculty of Mathematics and Natural Science, Universitas Negeri \\ Medan \\ atika.khovivah@gmail.com
}

Accepted: May 10th, 2021. Published: September 6th, 2021

\begin{abstract}
The Covid-19 pandemic has had a major impact on the order of life, especially in the world of education. Following Government Policy, the face-to-face teaching system is now being transferred to the online system or known as the online system. The problems that arise in choosing the right method to use in the teaching and learning process in the midst of this pandemic are a dilemma for teachers. Some of the alternative applications offered must be adapted to the conditions of the school, teachers and students. The application used must be able to be accessed and understood by every teacher and student so that learning objectives can be achieved. The focus of this research is the use of Google Classroom media in online learning and its advantages and disadvantages. Researchers conducted field research with a descriptive qualitative approach to the learning process in schools. The results show that online learning through Google Classroom has advantages and disadvantages. The advantages include that teachers can use various media for the learning process, both those contained in the Google Classroom or other media that can be linked to the classroom. While the drawbacks are network problems and the limited quota that students have can be an obstacle in the learning process, as well as the low level of student activity in the learning process. Almost 31 students who answered the questionnaire stated that Google Classroom was not very effective because it certainly could not replace face-to-face meetings. Because there are many things that cannot be done through google classroom.
\end{abstract}

Keywords: covid-19 pandemic, online learning, aplication Google Classroom 


\section{Introduction}

The COVID-19 pandemic (corona virus disease 2019) first appeared at the end of 2019 to be precise in Wuhan, China. COVID-19 is a virus that is transmitted very quickly and it is difficult to know the characteristics of people who have been infected with this virus because the incubation period is approximately 14 days. Almost all countries have experienced the impact of this pandemic, so many countries have set lockdown status and other anticipations to break the chain of the spread of COVID-19. As a result of this policy, many sectors were paralyzed, for example the main economic sector was paralyzed by this pandemic. Apart from the impacted economic sector, education is also one of the sectors that has also experienced the direct impact of this pandemic. According to UNESCO, there are at least 1.5 billion school-age children affected by COVID-19 from 188 countries, including 60 million of them in Indonesia. As a result of this pandemic schools were closed, this was done with the aim of preventing the spread of COVID-19.

Even though the school is closed, the teaching and learning activities or the learning process does not stop, based on a circular from the minister of education and culture that all learning activities are carried out using an online learning system at home. Online learning is a learning that is done remotely through the media in the form of the internet and other supporting tools such as cell phones and computers. Online learning is very different from learning as usual. Online learning emphasizes the thoroughness and foresight of students in receiving and processing the information presented online. The concept of online learning has the same concept as e-learning. During online learning, many parents complained about some of the problems faced while students were studying at home, including too many assignments and teachers who had not optimized technology.

One way that can be used to carry out the learning process online is by using Google Classroom. The use of Google Classroom can be through multiplatform, namely through computers and through devices. Through the Google Classroom application, it is assumed that learning objectives will be easier to realize and full of meaning. Therefore, the use of Google Classroom actually makes it easier for teachers to manage learning and convey information accurately and accurately to students (Hakim, 2016). Teachers can take advantage of various features found in Google Classroom such as assignments, grading, communication, time-cost, archive courses, mobile applications, and privacy.

Google classroom is an online learning application that can be used by all spheres of education that can help teachers and students share files in teaching and learning activities. Google Classroom can provide users with access to a content management system that allows users to post the latest updates on materials or assignments (Rozak, 2018). Google Classroom can be a means of distributing assignments, submitting assignments and even assessing submitted assignments (Nirfayanti and Nurbaeti, 2019). The use of Google Classroom actually makes it easier for teachers to manage learning and convey information accurately and accurately to students (Hakim, 2016). which is easy to use.

Research conducted by Shampa Iftakhar (2016) with the title Google Classroom: What Works and How? Contains that google classroom helps to monitor students for learning. The teacher can see all student activities during learning in Google Classroom. The interaction between teachers and students is well recorded. The features owned by google classroom according to Wikipedia (2017): Assignments (assignments), Grading (measurement), Communication (communication), Time-Cost (saving time), Archive Course (program archive), Mobile Application (applications in mobile phones) ) and Privacy (privacy). All of these features 
can be used by the teacher during learning. Teachers can easily learn usage by learning independently by looking at google support on google classroom.

This study aims to analyze the effectiveness of using Google Classroom as a learning medium during the current distance learning period, especially for junior high school students in North Sumatra.

\section{Research Method}

The research design used in this research was descriptive qualitative. The qualitative method means collecting data not in the form of numbers, but the data comes from interview scripts, field notes, personal documents, and other official documents (Napsawati, 2020). Qualitative methods emphasize the observation of phenomena and focus more on the substance of the meaning of these phenomena. The analysis and acumen of qualitative research are strongly influenced by the strength of the words and sentences used. The assessment approach is qualitative descriptive (case study), because the research will describe the current state of the research object based on existing facts (Nawawi \& Mini 1996).

This research was conducted online by distributing a form containing questions to 31 SMP / MTs students in North Sumatra. The focus in this study is to analyze the advantages and constraints of using Google Classroom during the distance learning process. The informants in this study were SMP / MTs students in North Sumatra. Data collection used in this study was to share a form containing several questions that had to be answered by the informants. In this study, data is presented in the form of narrative text and results diagrams. The presentation of the data begins with a description of the research results. After the data goes through the process, then an analysis is carried out in the discussion. The final step is drawing conclusions and verification. The conclusions that have been obtained during the field are then verified during the research by rethinking and reviewing field notes in the form of confirmation of conclusions.

\section{Result and Discussion}

Result

Google Classroom (Google Classroom) is an online learning application that can be used by all spheres of education that helps teachers and students share files in teaching and learning activities. Teachers can create their own class and share the class code or invite students. Google Classroom combines Google Drive for assignment creation and distribution, Google Docs, Sheets, Slides for writing, Gmail for communications, Google Calendar for scheduling, and Google Meet for video conferencing. In the early stages of 20142016 the development of google classrooms was not for everyone. People are only schools that collaborate with Google, but in March 2017 Google Classroom can be accessed by everyone using Google Personal. This can be used by teachers, students and student guardians in learning, so there is no need for collaboration with Google. Open use can provide benefits for google classroom users.

To use Google Classroom, teachers and students can access it using two ways, namely the website and the application. The website can be accessed using any browser such as Chrome, FireFox, or Internet Explorer. Meanwhile, applications can be downloaded for free through the Playstore for Android and the App Store for iOS.

Research conducted by Shampa Iftakhar (2016) with the title Google Classroom: What Works and How? Contains that google classroom helps to monitor students for learning. The teacher can see all student activities during learning in Google Classroom. The interaction between teachers and students is well recorded. The features owned by google classroom according to Wikipedia (2017):

1. Assigmenments (tasks)

2. Grading (measurement)

3. Communication (communication)

4. Time-Cost (save time)

5. Archive Course (program archive)

6. Mobile Application (application in mobile phone)

The responses given by the teacher to the use of google classroom include easy to use and have features that make it easy to create student attendance lists, share material, give assignments and give grades to these assignments. The materials 
distributed in the classroom can be various, ranging from material files, learning videos, and adding links that are linked to web pages or YouTube. In addition, google classroom does not fill up HP's memory because its storage is cloud-based. However, teachers often find it difficult to explain materials that contain physics equations. Low student participation in Google Meet. Many students were late filling in the attendance list and submitting assignments. Another problem encountered was that some students never filled out the attendance list and submitted assignments. Teachers prefer face-to-face learning in class rather than online learning.

Table 1. Ease of Indicators

\begin{tabular}{|c|c|c|c|c|}
\hline $\begin{array}{c}\text { Ease of using Google } \\
\text { Classroom }\end{array}$ & TS & RG & $\mathbf{S}$ & $\overline{S S}$ \\
\hline $\begin{array}{l}\text { Is using Google } \\
\text { Classroom easy to learn }\end{array}$ & - & $\begin{array}{l}22 \\
71 \%\end{array}$ & $\begin{array}{c}9 \\
29 \%\end{array}$ & - \\
\hline $\begin{array}{l}\text { Is the display on the } \\
\text { Google Classroom } \\
\text { menu easy to use }\end{array}$ & - & $\begin{array}{l}22 \\
71 \%\end{array}$ & $\begin{array}{c}9 \\
29 \%\end{array}$ & - \\
\hline & & & $\begin{array}{l}\text { - dise } \\
\text { do do } \\
\text { agr } \\
\text { strc } \\
\text { agr }\end{array}$ & \\
\hline
\end{tabular}

Diagram 1. Is the use of Google classroom easy to learn?

The ease of using Google Classroom is difficult to learn as evidenced by the results of the questionnaire with statements from 22 students or about $71 \%$ of students who still expressed doubts this was based on the lack of understanding of students regarding the use of Google Classroom. And only 9 students or $29 \%$ agreed to use Google Classroom.

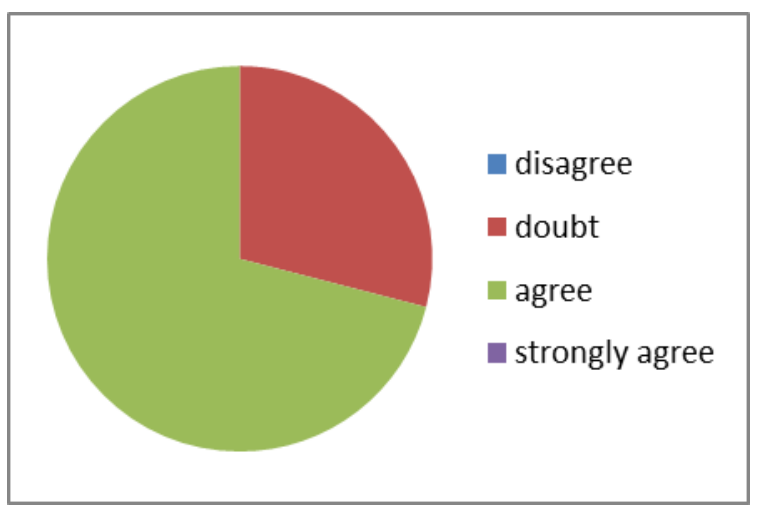

Diagram 2. Is the display on the Google Classroom menu easy to use?

Table 2. Constraint Indicators

\begin{tabular}{|l|c|c|c|c|}
\hline \multicolumn{1}{|c|}{$\begin{array}{c}\text { Constraints using } \\
\text { Google Classroom }\end{array}$} & TS & RG & S & SS \\
\hline $\begin{array}{l}\text { Are internet quotas } \\
\text { and network a barrier } \\
\text { for me in online }\end{array}$ & 4 & 2 & 15 & 10 \\
learning using Google & & & 48 & \\
Classroom & 13 & 6,5 & $\%$ & 32 \\
& $\%$ & $\%$ & & $\%$ \\
& & & & \\
\hline
\end{tabular}

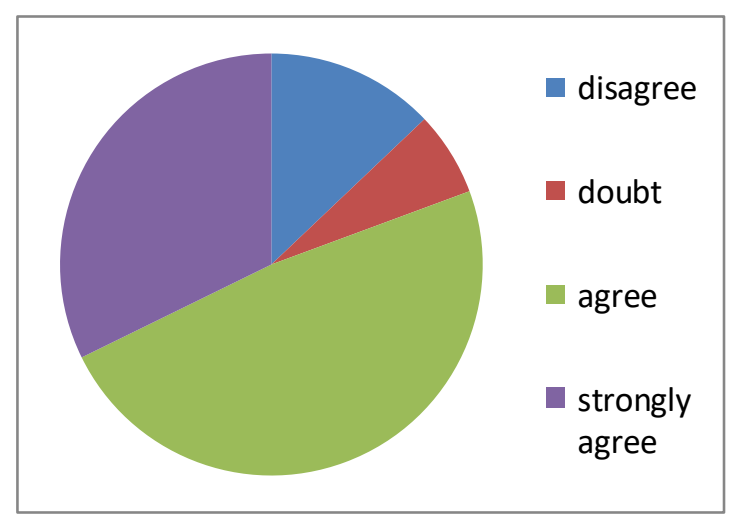

Diagram 3. Are quotas and internet networks an obstacle for me in online learning using Google Classroom?

Regarding the statement above, 15 of the 31 students who answered agreed that the quota and internet internet network were a barrier for me in online learning using Google Classroom, 10 students or $32 \%$ answered strongly agree, while 4 students or $12.9 \%$ answered disagree and Finally, only 2 students answered doubt about the statement.

Does Google Classroom make it 
easier for students to collect material assignments and get announcements, related to this statement 24 students (77\%) answered agree, while only 4 students answered strongly agree and 3 other students answered doubtful.

Table 3. Learning success using Google

Classroom

\begin{tabular}{|c|c|c|c|c|}
\hline $\begin{array}{c}\text { Success in using } \\
\text { Google Classroom }\end{array}$ & $\begin{array}{l}\mathbf{T} \\
\mathbf{S}\end{array}$ & RG & $\mathbf{S}$ & SS \\
\hline $\begin{array}{l}\text { Does Google } \\
\text { Classroom make it } \\
\text { easier for you to get } \\
\text { announcements, } \\
\text { materials and } \\
\text { assignments? }\end{array}$ & - & $\begin{array}{c}9,7 \\
\%\end{array}$ & 24 & $13 \%$ \\
\hline
\end{tabular}

The display on Google Classroom is difficult to understand, this states that it is difficult for 22 students out of 31 students who filled out the questionnaire as if $71 \%$ of students still expressed doubt, and only 9 students or $29 \%$ answered agreed.

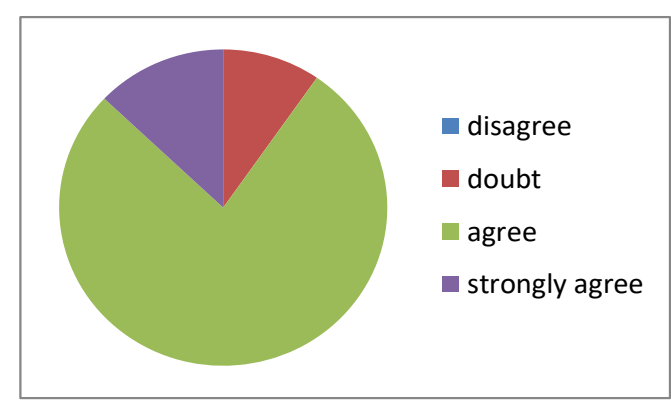

Diagram 4. Does Google classroom make it easier for me to get material announcements and submit assignments?

Online learning using Google Classroom has advantages and disadvantages. Students and teachers agree that the google classroom is easy to use and helps the learning process during this pandemic and does not make HP's memory full because everything shared in the classroom is stored in cloud-based storage (Mahardini, 2020). To provide material, teachers find it difficult when have to discuss material that has a lot of formula equations and students also find it difficult to understand the material. This may be tricked by making a learning video containing the teacher explaining these equations and for the delivery of the material also selected essential competencies if easier for students to understand. The learning process is also sometimes less conducive due to various factors. The many types of internet providers used by students, each of which has different internet network strengths and also the limited quota owned by students, causes the learning process to be not optimal.

Table 3. Do you think Google Classroom can replace face-to-face learning in schools? give the reason!

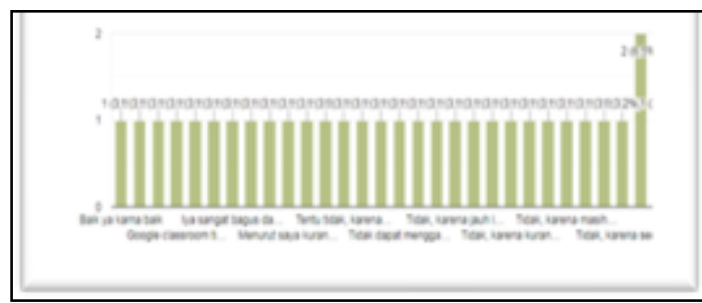

Students who answered this question, almost 31 students who answered the questionnaire, stated that it was not very effective because Google Classroom certainly could not replace direct meetings. Because there are many things that cannot be done through google classroom compared to directly and also related to the menu on Google Classroom which is still small so it is still less effective in its use.

The use of Google Classroom media in online learning is quite effective in being used as an alternative media that supports the learning process. But in fact, according to the results of Hardinata A. (2020) research, it is stated that there were still few lecturers or teachers who use google classroom in learning. However as previously explained, Google Classroom has several advantages and disadvantages. The advantages of google classroom according to Janzem in Iftakhar (2016: 13) are easy to use, save time, cloudbased, flexible, and free. This is a 
consideration that google classroom is appropriate for primary and secondary schools. Even though it still has weaknesses such as the absence of external services such as automatic question banks and private chat between teachers for feedback (Pappas, 2015). Network problems and the limited quota that students have can be an obstacle in the learning process, as well as the low level of student activity in the learning process. In addition, the teacher finds it difficult to explain material that contains physics equations, students also have difficulty understanding the material which has an impact on the low ability of students to solve calculation problems. Google classroom learning in schools targets students who are already in high class. Higher grade students have an interest in concrete practical, everyday life. According to Mulyani and Syaodih (2009: 15) high class students are at the stage of investigating, trying, and experimenting. Students at that age are technology literate, ready to accept the times through existing technology.

\section{Conclusion}

The use of Google Classroom as an online learning medium is less effective in achieving learning goals. This is due to several factors, including the lack of material explanation by the teacher, students lack of understanding of the material being taught, the influence of internet (network) signals on the learning process, and due to the busyness of parents which results in students being less attentive to doing this online.

\section{Reference}

Azhar, K. A., \& Iqbal, N., (2018), Effectiveness of Google classroom: Teachers' perceptions, Prizren Social Science Journal,2(2) : 52-66.

Belawati, Tian., (2019),Pembelajaran Online, Penerbit: Universitas Terbuka.

Hardinata, A., dkk. 2020. Survey On The Effectiveness Of Online Lecturres During Covid-19 Pandemic:
Mehods and Difficulties. Jurnal Unimed. Vol. 2. No. 2. 7-12.

Hakim, Abdul Bahrir,. (2016), Efektifitas Penggunaan E-Learning Moodle, Google Classroom dan Edmodo, ISTATEMENT2(1).

Herliandry, L. D., dkk., (2020), Pembelajaran Pada Masa Pandemi Covid-19, JTPJurnal Teknologi Pendidikan22(1): 65-70.

Iftakhar, Shampa., (2016), Google Classroom: What Works and How?, Journal of Education and Social Sciences 3 : 12-18.

Kurniawan, B., dkk., (2020), Pelatihan Penggunaan Aplikasi Google Classroom Sebagai Upaya Peningkatan Pembelajaran Online, International Journal of Community Service Learning4(1) : 1-9.

Mahardini, Maya M.A., (2020), Analisis Situasi Penggunaan Google Classroom pada Pembelajaran Daring Fisika, Jurnal Pendidikan Fisika8(2): 215 224.

Mona, N., (2020), Konsep Isolasi Dalam Jaringan Sosial Untuk Meminimalisasi Efek Contagious (Kasus Penyebaran Virus Corona di Indonesia, Jurnal Sosial Humaniora Terapan2(2) : 117125.

Nadziroh, F., (2017), Analisa Efektifitas Pembelajaran berbasis E-Learning, Jurnal Ilmu Komputer dan Desain Komunikasi Visual 2(1) : 1-14.

Napsawati, N., (2020), Analisis Situasi Pembelajaran Ipa Fisika Dengan Metode Daring Di Tengah Wabah Covid-19. Karst: jurnal pendidikan fisika dan terapannya, 3(1) : 6-12.

Nawawi, H., \& Mini M., (1996), Penelitian Terapan, Yogyakarta : Gajah Mada University Press.

Nirfayanti., \& Nurbaeti., (2019), Pengaruh Media Pembelajaran Google 
Classroom dalam Pembelajaran Analisis Real Terhadap Motivasi Belajar Mahasiswa, Jurnal Penelitian Matematika dan Pendidikan Matematika2(1) : 50-59.

Palvia, S., dkk., (2018), Online Education: Worldwide Status, Challenges, Trends, and Implications, Journal of Global Information Technology Management43: 1-14.

Purwanto, Agus., dkk., (2020), Studi Eksploratif Dampak Pandemi COVID19 Terhadap Proses Pembelajaran Online di Sekolah Dasar, Journal of Education, Pshychology and Counseling 2(1).

Purba, R., dkk., (2020), Pembelajaran Berbasis Google Classroom, Geoogle Meet dan Zoom Guru SMP Negeri 2 Batubara, Jurnal Pengabdian Kepada Masyarakat 1(4) : 410-416.

Rozak, A dan Albantani A.M., (2018), Desain Perkuliahan Bahasa Arab Melalui Google Classroom, Jurnal Pendidikan Bahasa Arab dan Kebahasaaraban5(1) : 83-102. 